\title{
Funkcjonowanie pojęcia prawdy na przykładzie potocznego użycia „tak naprawdę"
}

\section{Functioning of the Notion of Truth on the Example of Colloquial Use of the Expression "tak naprawdę"}

\author{
Bożena Niećko-Bukowska \\ INSTYTUT JĘZYKOZNAWSTWA, UNIWERSYTET IM. ADAMA MICKIEWICZA \\ AL. NIEPODLEGŁOŚCI 4, 61-874 POZNAŃ \\ bniecko@amu.edu.pl
}

\begin{abstract}
This article is motivated by the interest in the colloquial spoken language. A concise description of chosen definitions of the idea of truth is presented. The author looks at the phrase „tak naprawdę" used in selected examples of colloquial sentences. She investigates the reasons of the use of this phrase in both formal and informal, social lifes situations. The article aims at showing various meanings of "tak naprawdę" like: "in reality", "strictly speaking", "frankly speaking", "to tell you the truth", "in general", "actually", "in principle"... In this context the problems of the methaphoricity of truth and the phenomenon of multi- ambiguity of truth are discussed.
\end{abstract}

\section{Wstęp}

Słowem wstępu należy nadmienić, że artykuł ten wyrasta na bazie zainteresowań żywym językiem. W skrócie przedstawione zostaną przykładowe koncepcje prawdy. Poruszone będzie zagadnienie funkcjonowania prawdy w przestrzeni społecznej oraz sensów jakie ludzie prawdzie nadają i jak ją odczytują. Przykładowo, używa się takich zwrotów jak: prawdę mówiąc, szczerze mówiąc, w gruncie rzeczy, w istocie sprawy oraz wyrażeń: na pewno, naprawdę. Warto zastanowic się, skąd ta potrzeba nazywania faktów nie jakimi są, ale „tak naprawdę” jakimi są? Zastanawiające, czy przyczyn tego stanu rzeczy nie można doszukać się w rozpowszechnionym relatywizmie, czy też przekonaniu o niemożliwości osiągnięcia prawdy absolutnej. W świecie, w którym nieszczerość funkcjonuje w każdej sferze życia, potrzeba prawdy przybiera na sile. Czy, kiedy „naprawdę” traci swoją prawdę i przybiera postać pozoru, „tak naprawdę” staje się sposobem na powiedzenie prawdy, na podkreślenie szczerości wypowiedzi, na zwiększenie jej mocy sprawczej?

\section{Wyrażenie tak naprawdę w kontekście definicji prawdy}

Prawda, pewność czy oczywistość uchodzą za słowa klucze epistemologii. Pojęcia te służą do odróżniania mniemania od wiedzy i poznania. Rozważania epistemologiczne nad istotą pewności, prawdziwości, oczywistości dostarczają bagoctwa materiału z zakresu tematyki kryteriów prawdy, źródeł (czy granic) poznawania. 
Zwykło się przyjmować następujące definicje prawdy: klasyczną i nieklasyczne. W przypadku klasycznej koncepcji za kryterium prawdziwości uchodzi zgodność myśli z rzeczywistością. Ta klasyczna (zwana korespondencyjną) teoria zakłada, że prawda polega na odpowiedniości między rzeczywistością a wypowiadanymi sądami. Natomiast na gruncie nieklasycznych definicji prawdy nie ma znaczenia, czy twierdzenie jest zgodne z rzeczywistością, czy też nie, liczy się tylko, czy jest zgodne z ostatecznymi kryteriami. Jedno z kryteriów jakie przyjmowano, stanowi zgodność myśli między sobą. Podstawą uznania w ramach tej koherencyjnej definicji prawdy twierdzenia za prawdziwe, było sprawdzenie, czy daje się ono harmonijnie włączyć do grona już przyjętych twierdzeń, czy nie popada ono z nimi w sprzeczność, a więc postuluje się spójność między twierdzeniami. Kolejne kryterium to powszechna zgoda. Jeszcze inne, oczywistość - kartezjańska rozumiana, jako jasne i wyraźne przedstawienie sobie stanu rzeczy, do którego dany fakt się odnosi.2 Dla Kartezjusza, oczywistość stanowi podstawę do orzekania o prawdziwości danego twierdzenia. Tylko twierdzenia oczywiste są prawdziwe. Warto jednak nadmienić, że oczywisty może być także fałsz. Poza jasnością i wyraźnością, oczywistość cechuje zrozumiałość, stąd sąd oczywisty to taki, który może zostać pojęty przez każdą zdrowo myślącą osobę na mocy znaczenia zawartych $\mathrm{w}$ wypowiedzi terminów. Za niewątpliwe i tym samym oczywiste uchodzą powinności moralne. Przykładem kartezjańskiej oczywistej idei - jasnej i wyraźnej jest idea Boga, ale również idea siebie samego, trójkąta...

Interesującym przypadkiem nieklasycznej definicji prawdy jest pragmatyczna koncepcja prawdy, utożsamiająca prawdziwość twierdzenia z pożytecznością. Takie ujęcie prawdy bierze się z definiowania prawdziwości w oparciu o użyteczność danego twierdzenia w działaniu - ,jeśli idee teologiczne okazują się wartościowe dla życia konkretnego, będą one prawdziwe dla pragmatyka w tym znaczeniu, iż są do tego dobres", i zdaje się być bliske przekonywającemu charakterowi użycia wyrażenia tak naprawdę, chociaż "tak naprawdę" odsyła, na pierwszy rzut oka, do klasycznego pojmowania prawdy.

Kiedy z przestrzeni naukowej prawdziwości, oczywistości przenośmy się do świata języka potocznego, poruszamy się w sieci tego, co jest "oczywiste", "na pewno", "tak naprawdę". U podłoża mówienia o czymś, że jest "tak naprawdę", leży przeświadczenie, że zachodzi zgodność między myśleniem, mówieniem a rzeczywistością. Tak jest przy klasycznym rozumieniu prawdy. Inaczej sprawa się przedstawia, kiedy analizujemy ją z perspektywy użycia "tak naprawdę", jako wyrażenia przysłówkowego o charakterze perswazyjnym. Przy tym ujęciu, podkreślanie za pomocą "tak naprawdę" wypowiedzi, ma na celu przekonać słuchacza do swoich racji. Ten element perswazyjny wiąże się z budowaniem wrażenia u odbiorcy komunikatu o słuszności zastosowanej argumentacji, z próbą przedstawiania świata jako zgodnego z tym, co mówimy, a cała wypowiedź może przybrać zręczną postać chwytu erystycznego. Wyrażenie "tak naprawdę" używane bywa przy nakłanianiu, manipulowaniu, przekonywaniu, perswadowaniu. Ciekawostką jest to, że zawsze przy dającym się zauważyć założeniu o przyjmowaniu wizji świata zgodnej z arystotelesowską koncepcją prawdy. Obok

\footnotetext{
${ }^{1}$ [Ajdukiewicz, 1983: 15-23

2 [Zob., Tamże: 23-30]

3 [James: 1957: 48]
} 
silnego elementu epistemicznego, na podkreślenie zasługuje jego element aksjologiczny. Wartością, w oparciu o którą próbuje się budować wypowiedzi zgodnie z arystotelesowskim duchem, jest prawda, odrzucająca relatywizm na rzecz obiektywizmu. W takim przypadku to możliwy przejaw tęsknoty, a nawet wiary w to, co jest "tak naprawdę", a nie tylko na żarty, na pokaz.

\section{Analiza wyrażenia tak naprawdę na wybranych przykładach}

Przykłady popularnych sposobów użycia wyrażenia tak naprawdę:

- „Mogło dojść tak naprawdę do krwawej jatki”.

- „Oni powinni tych przestępców tak naprawdę zabić”.

- „”Tak naprawdę główny problem polega na tym, kim jestem”.

- „... i nic by się nie zmieniło tak naprawdę”.

- „Oni tak naprawdę nie mają złych intencji”.

- „Ja myślę, że tak naprawdę to nie jest konieczne”.

- „Już tak naprawdę było wiadomo, że jest katastrofa”.

- "Okazało się, że w sklepach tak naprawdę nie ma w czym wybierać".

Zgodnie z tezą Herdera-Humboldta w wypowiedziach tych zawarta jest pewna forma myślenia. Cechą, zawatego $\mathrm{w}$ tych zdaniach wyrażenia tak naprawde jest jego konotacja z następującymi zwrotami: „powiedzmy otwarcie”, „powiedzmy sobie szczerze”, „miedzy Bogiem a prawdą”, „między nami mówiąc”, czy „prawdziwe/ukryte przesłanie (czegoś)”, „głębszy/ukryty sens (np. wypowiedzi, działań)”.

Można zauważyć, że wypowiadający „tak naprawdę”, próbuje za pomocą tego wyrażenia wzmacniać swoją argumentację, podkreślając autentyczność zawartych w zdaniu treści. Tak wyjaskrawia głoszone przez siebie sądy, zwraca uwage na główny problem oraz akcentuje wypowiedź.

„Tak naprawdę” funkcjonuje również jako zamiennik z „nie na żarty”. „Tak naprawdę to chciałem Ci powiedzieć, że...” znaczy, iż mówiący nie żartuje, tylko mówi na poważnie. Natomiast w zdaniu: „tak naprawdę to Cię lubię”, mamy do czynienia z próbą powiedzenia, że „szczerze Cię lubię”. Możliwym czynnikiem generującym takie wypowiedzi jest zjawisko nieszczerości. Ile razy usłyszeć można „lubię Cię”, i jak wiele razy okazuje się to fałszem? Udawane darzenie sympatią dla realizacji własnych zamierzeń, płytkość zawieranych przyjaźni, to smutne przesłanki dla poszukiwań tego, co jest autentyczne, dla tego, co jest „tak naprawdę".

„Tak naprawdę” wypada odróżnić od „Tak. Naprawdę...” Partykuła „tak” jest logicznym potwierdzeniem, wyrażeniem zgody na to, co zostało powiedziane przez interlokutora. Natomiast „naprawdę” rozpoczyna następny ciąg zdaniowy i znaczy: faktycznie, w rzeczywistości. Inaczej rzecz się przedstawia w przypadku „Tak. Naprawdę...?” - kiedy to mamy do czynienia z zadanym pytaniem i "naprawdę" znaczy „czy na pewno?”. Nietrudno wyobrazić sobie taki dialog. -„Pójdziemy do teatru?”-„Tak. [oraz pytanie:] Naprawdę chcesz iść do teatru?” Bardzo zbliżonym przypadkiem jest „ale tak naprawdę?”, co oznacza nie więcej niż - „ale bez żartów, szczerze?”. Niejednego prawdopodobnie czytelnika zastanawia, dlaczego zamiast naprawdę, coraz częściej słychać tak naprawdę? Dlaczego naprawdę potrzebuje wzmocnienia partykułą tak? Zjawisko to, przez niektóre osoby może być poczytane nie tyle nawet za błąd, co za przejaw skrywanej nieszczerości. Na pewno nie poprawiają tej sytuacji użycia, w których na sile przybierają formy (można 
zaryzykować) nadużyć. „Tak naprawdę to wybiła dwunasta”. Dlaczego akurat nie „Wybiła dwunasta”? Czyżby „tak naprawdę” odgrywało, w niektórych przypadkach rolę wygodnego przerywnika?

Innym użyciem jest rozumienie „tak naprawdę” jako „w ogóle”: „Ludzie tak naprawdę (w ogóle) nie myślą". Mamy tutaj wyraźną próbę podkreślenia, że definitywnie, wcale, w żadnym razie " ludzie nie myślą”. Zauważa się przy tym, przemycanie wizji świata, w ramach to której za prawdę ma być uznane to, co głosi mówca, niezależnie od tego, jaka prawda by nie była. To prawda subiektywna, a całość może być uznana za próbę wzbudzenia emocji, wywierania wpływu, manipulacji, skłonienia do własnego punktu widzenia. To wypowiedz, której siła leży w przekonywaniu.

Dalsze przykłady: „...wszyscy myśleli, że tak naprawdę wszystko się dobrze skończy”; „...i tak naprawdę nic więcej nie można było zrobič”; „...bo tak naprawdę film rozgrywa się na przestrzeni 30 lat”; „MSZ zaciskało pasa, gdy to nie było tak naprawdę potrzebne”; „Mówimy o podróżach do miejsc, do których jest teraz modnie tak naprawdę pojechać". W wypowiedziach tych tak naprawdę można oddać za pomocą $w$ rzeczywistości. W ramach takiego funkcjonowania wyrażenia przysłówkowego tak naprawdę, mamy do czynienia $\mathrm{z}$ przyjmowaniem obrazu świata zgodnego $\mathrm{z}$ arystotelesowskim pragnieniem odzwierciedlania rzeczywistości, adekwatności między myśleniem i słowami. Dalsze przykłady: „Tak naprawdę wymiana tej waluty oznacza, że złotówka zyskuje na giełdzie”, czy „Ministerstwo rozpoczęło interwencję na rynku w związku ze słabym kursem złotego. Co to tak naprawdę oznacza, zapytam za 10 minut eksperta”. Przykłady te dalej wskazują na używanie wyrażenia tak naprawdę zamiennie $\mathrm{z} w$ rzeczywistości. W zdaniu - „To jest ostatnia okazja, żeby o coś jeszcze zapytać tak naprawdę”, tak naprawdę odsyła do szczerze, prawdziwie. Dobrze oddaje szczerze, za pomocą tak naprawdę zdanie o treści: „Tak naprawdę to sam do końca nie rozumiem". Wstawienie tak naprawde $\mathrm{w}$ miejsce szczerze, bądź $w$ szczególności ma miejsce w przypadku zdania o treści: „Zależy od tego, kto jedzie ale tak naprawdę zależy od systemu wartości”. Jak widać szczerze, to nie to samo co $w$ szczególności. Szczerość tej wypowiedzi polegałaby na podzieleniu się przeświadczeniem o kluczowej roli sytemu wartości, natomiast ujęcie w ramach szczególności odsyła oczywiście do elementu systemu wartości ale nie usuwa w cień roli osoby.

Oryginalnym, ale i czy nie karkołomnym zastosowaniem w wypowiedzi tak naprawdę jest użycie go w poniższej postaci - „oni tak naprawdę w gruncie rzeczy opiekują się troskliwie chorą osobą”, „ludzie Ci tak naprawdę robiąc to co robią, muszą być prawdziwi”. Tak naprawdę i $w$ gruncie rzeczy obok siebie postawione, przypominają próbę opisania stanu rzeczy, w którym prawdą jest, że „w istocie rzeczy/sprawy opiekują się troskliwie chorą osobą”.

Kolejnym przykładem użycia tak naprawdę będzie zastosowanie go jako: między nami mówiąc, powiedzmy sobie prawdę, prawde mówiąc, uczciwie mówiąc. W tej postaci użycie to pozwala na zaakcentowanie skrywanej prawdy, na wydobycie na światło dzienne tego, co się rzeczywiście myśli, bądź odczuwa. Za pomocą między nami mówiąc, lub nie będę ukrywat, że... można zastąpić wyrażenie tak naprawdę w zdaniu: ,...ale tak naprawdę możemy zrealizować tylko połowę inwestycji”. Trzeba nadmienić, że mamy tutaj do czynienia z próbą wyznania, powiedzenia „czegoś” szczerze, nie ukrywania dłużej prawdy poprzez odsłonięcie faktów. Podobnie jak w przypadku zdania o treści - „Madonny 
słuchałem po kryjomu, żeby nie narazić się kolegom, ale wszyscy jej słuchali, tak naprawdę".

W niektórych przypadkach, w określonym kontekście sytuacyjnym, jak w: „znaleziono tak naprawdę 10 miliardów”, tak naprawdę może znaczy tyle, co przecież. Czasem wypowiedź z użyciem tak naprawdę, taką jak: „bo tak naprawdę o to chodzi” da się zastąpić przez - „to jest właśnie to”.

Profesor Jadwiga Puzynina analizując wyrażenia i pojęcia podstawowe dla semantyki i pragmatyki wartości, zwraca uwagę na wyrazy właściwie i właściwy. Pomija jednakże ich znaczenia modalne: 'ściśle biorąc' oraz 'prawdę mówiąc', przysłówka wlaściwie oraz znaczenie 'rzeczywisty, prawdziwy' przymiotnika właściwy4. Właśnie w zdaniu - „Tak naprawdę nie wiadomo, komu udało się odszukać i sprowadzić doktora do dziupli wiewiórki i jej chorego synka5", tak naprawdę znaczy: właściwie, w rzeczy samej, w istocie sprawy, ściśle biorąc, prawdę mówiąc.

Tak naprawdę może oznaczać również $w$ zasadzie. Przykład: „Świat jest tak naprawdę dobry", czyli taki jaki nadawca chce, żeby był, albo taki jakim go nadawca widzi. Zastąpienie tak naprawdę przez $w$ zasadzie, nie zmienia faktu, że nadawca ma na myśli pewien wykaz głównych cech, ze względu na które wypowiada dany sąd, stwierdzający, że przedmiot czy zjawisko jest prawdziwie dobre.

W wypowiedzi - „to tak naprawdę nie ma większego znaczenia”, tak naprawdę może wyrażać: znaczenia;

-szczerze, między nami mówiąc: Szczerze, to nie ma większego -istotnie, $w$ gruncie rzeczy: Istotnie (w gruncie rzeczy), to nie ma większego znaczenia;

$>\quad-w$ zasadzie, właściwie, ściśle biorąc: $\mathrm{W}$ zasadzie to nie ma większego znaczenia;

$>\quad-w$ ogóle, wcale: $\mathrm{W}$ ogóle to nie ma większego znaczenia.

Szczerze, między nami mówiąc zwraca uwagę na nić porozumienia i wyznania. Istotnie podkreśla zgodny charakter opinii i służy do potwierdzania. $W$ zasadzie, właściwie określa w tym przypadku warunki pod jakimi „to nie ma większego znaczenia”. W ogóle, wcale akcentuje, że „dany stan” nie ma znaczenia.

\section{Pragmalingwistyczny charakter tak naprawdę}

Jakie intencje przyświecają wypowiedziom? Zdaniem J.L. Austina oraz J. R. Searle'a intencja jest polem istnienia takich językowych funkcji pragmatycznych jak: funkcje modalne, emocjonalne oraz działania. Natomiast A. Wierzbicka wyróżnia postawę interakcyjną, którą nazywa oznajmieniem, i z eksplikacji której wynika, „że mówiący prezentuje wolę poinformowania odbiorcy o czymś i przekonanie co do prawdziwości wypowiadanych sądów"6.

Bywa, że intencją stojącą za użyciem wyrażenia „tak naprawdę”, jest pragnienie podzielenia się szczerze własnymi uwagami, spostrzeżeniami na jakiś temat. Mamy tutaj do czynienia $\mathrm{z}$ chęcią powiedzenia prawdy. Poruszamy się $\mathrm{w}$

\footnotetext{
4 [Zob. 1992: 91]

5 Cytat z: "Wróbelek Maciuś w Afryce i inne bajki", E. Janikowska, s.28.

${ }^{6}$ [Zob., Grabias, 2003: 289-290]
} 
świecie ludzi pragnących komunikować się otwarcie i wierzących, że jest to możliwe. Intencja ta jest zgodna z korespondencyjną koncepcją prawdy. Nie jest to jednak jedyna intencja sprzyjająca użyciu „tak naprawdę”. Obok niej spotykamy także motywy perswazyjne. W nich to „tak naprawdę" ma za zadanie wzmocnić siłę przekonywania, ma za cel skłonić, wyperswadować. Perlokucyjność zawarta w takich aktach idzie w parze z manipulacyjnym użyciem słów. Warto wspomnieć, .że takie użycie zgodne jest $\mathrm{z}$ habermasowskim rozumieniem perlokucji. Intencją przyświecającą zastosowaniu w wypowiedzi „tak naprawdę” będzie tutaj głównie przekonywanie a nie mówienie szczerze, tego co się myśli.

Jak widać z powyższych przedstawień użycia tak naprawdę, wyrażenie to pada zarówno $\mathrm{w}$ kontaktach oficjalnych: $\mathrm{w}$ rozmowach na tematy profesjonalne, chociażby $\mathrm{w}$ trakcie konferencji naukowej; $\mathrm{w}$ trakcie rozmów indywidualnych, przykładowo służbowych; w wypowiedziach sterujących zachowaniem słuchaczy w radiu, w telewizji, jak i w kontaktach nieoficjalnych: podczas rozmów rodzinnych, towarzyskich, rozmów osób nieznajomych, np. w tramwaju.

Przyjrzyjmy się raz jeszcze pojęciu „prawdy”. W semantyce przyjmuje się definicję prawdy, odwołującą się do pojęcia spełnienia. Cechą wyróżniającą takich twierdzeń zgodnych z intuicją, jest to, że zdanie jest prawdziwe albo fałszywe, że konsekwencje zdań prawdziwych są zdaniami prawdziwymi. Pozwala to ustrzec się przez antynomią kłamcy. Jednakże nie jest to możliwe w przypadku języka potoczneg07. Odpowiedź na pytanie czemu przysługuje prawdziwość: zdaniom, sądom w sensie logicznym, czy może aktom wydawania sądów, jest problemem z pogranicza logiki i filozofiis.

Rozważania powyższe nasuwają wniosek, że użycia wyrażenia przysłówkowego tak naprawdę, wiele wspólnego mają z sofistycznym sposobem traktowania słów. Sofiści należeli do tych myślicieli, którzy dostrzegli pragmalingwistyczny charakter słów. Przykładowo: Protagoras z Abdery, zasłynął z tego, że głosił iż, „człowiek jest miarą wszystkich rzeczy, istniejących, że istnieją, i nie istniejących, że nie istnieją". Myśliciel ten odrzucił absolutne kryterium prawdy i założyl, że jedynym kryterium jest jednostkowy człowiek. Inne jego sławne twierdzenie, że „o każdej rzeczy istnieją dwa sądy wzajemnie sprzeczne"1o podkreślało względny charakter prawdy. Przeświadczenie, o tym, że człowiek jest miarą wszystkich rzeczy pozwalało przyjąć Protagorasowi za prawdę nie tylko dwa wzajemnie wykluczające się sądy, ale służyło ukazaniu, że ludzkie sądy wiążą się silnie ze sferą doznań. Dlatego nie dziwi, że prawda ujęta została przez niego subiektywnie a wszelka wiedza uznana została za pozorną. Umiejętność wymowy, retoryczne zdolności to narzędzia konieczne dla skutecznego kierowania ludzkimi myślami, uczuciami, doznaniami. Mowa dla Protagorasa to instrument pozwalający uczynić „z gorszej sprawy lepszą"11.

Słynny ze swej erystycznej błyskotliwości, Gorgiasz poszedł znacznie dalej. W rozważaniach nad istotą prawdy w „O naturze albo o niebycie”, zanegował byt, absolutną prawdę, myśl jako nośnik bytu i prawdy oraz słowa, które ten byt i myśl objawiają. Słowo uzyskało u niego pełną autonomię. Stało się nośnikiem sugestii,

\footnotetext{
7 [Mała encyklopedia logiki, 1970: 215-216]

8 [Tamże, 217]

9 Zob. [Reale, 1994: 247]

10 Zob. [tamże: 249].

${ }^{11}$ Zob.[Legowicz, 1986: 126-127]
} 
perswazji i przekonywania12. Według Gorgiasza wszystko co istnieje, jest fałszem, więc żadna prawda nawet ta względna nie istnieje. Celem jaki prześwieca słowom jest manipulacja ludzkimi uczuciami, przekonaniami i myślami. Słowa nie służą wyrażaniu zgodności między ludzkim myśleniem a rzeczywistością. Słowa mają kształtować ludzkie uczucia zgodnie ze zgłaszanym zapotrzebowaniem politycznym, i na tym też ma polegać skuteczność słów. Sofiści byli świadomi, że mowa jest swoistym narzędziem walki także politycznej. Wzorcem osobowym staje się „umieć na ludzi przekonująco działać słowami [...], w sądzie skłaniać sędziów, a w radzie radców, a na zgromadzeniu publicznym publiczność i na każdym innym zebraniu, jakie tylko bywają zebrania obywatelskie"13.

Niewątpliwą zasługą sofistów było ukazanie ówczesnym ludziom nowego świata rozumu, myśli i mowy, wprowadzenie ich $\mathrm{w}$ dziedzinę dialektyki argumentowania „za” i „przeciw”, przyczynienie się do rozwoju wiedzy o prawie, społeczeństwie, aksjologii, zwłaszcza w zakresie moralności, wzbogacenie języka filozoficznego, nauczanie analizy znaczenia wyrazów i ich określania"14. Zapoczątkowali nowe użycie języka w społeczeństwie. Odkryli, że stanowi on silny instrument sugestii, manipulacji i perswazji. Kluczowym zadaniem dla sofistów było nauczanie skutecznych chwytów w dziedzinie walki na słowa, zbijania argumentów przeciwnika i pozyskania słuchacza. Niejednokrotnie wiązało się to z użyciem manipulacji, przeobrażaniem ludzkich myśli, uczuć, doznań i postaw. Natomiast głoszony relatywizm i brak absolutnej prawdy doskonale wpisywał się w naukę czynienia słabszych argumentacyjnie sądów silniejszymi.

Instrumentalne potraktowanie języka odnajdujemy także w XX-ej filozofii Ludwika Wittgensteina. Myśliciel ten ujmuje język naturalistycznie, dostrzega w nim środek do wyrażania ekspresji oraz widzi w nim narzędzie komunikacji. Głosi, że znaczenie słów to ich użycie, że znaczenie wyrazu zależy od kontekstu użycia. Nieznajomość, niepoprawność użycia słów-narzędzi utrudnia porozumiewanie się, bo sam proces używania słów stanowi dla niego właśnie jedną z gier językowych ${ }^{15}$. W swoich Dociekaniach filozoficznych podkreśla, że mówienie jest pewnym sposobem życia ${ }^{16}$. Jeśli znamy reguły gry - użycia słów, to wiemy, co słowa znaczą i umiemy grać. Reguły są więc bardzo użyteczne, regulują one normalne użycia słów.

Wszelkie przypadki „nienormalne” powstają zdaniem Wittegesteina na skutek wadliwego użycia języka ${ }^{17}$. Zauważa, że reguły stanowią efekt socjalizacji i dlatego kierowanie się regułą jest pewną praktyką ${ }^{18}$. Postuluje, by „badanie sposobu użycia danego słowa w grze językowej" polegało głównie na określeniu celu, jakiemu ono służy”. Nasze słowa, które są właściwie „pionkami w grze językowej” charakteryzuje to, iż powstają $\mathrm{z}$ połączenia sposobu, $\mathrm{w}$ jaki funkcjonują $\mathrm{w}$ poszczególnych „rozgrywkach” z potoczną wiedzą, jaką na temat danego pojęcia dysponuje „gracz” 19. Jaki cel - uświadamiany, czy też nie, przyświeca nadawcy, który używa, w wypowiadanych przez siebie zdaniach, wyrażenia tak naprawdę?

\footnotetext{
12 [Reale, 1994: $264-268]$.

13 [Platon, 2002: Gorgiasz, 452 e]

14 [Legowicz, 1986: 136-137]

15 Zob.[Chapman, 2000: 112]

16 Zob.[Wittgenstein, 2000: 11-14].

17 Zob. [ibidem: s. 29, 61, 87]

18 [ibidem: 120, 125]

19 [Wołos, 2002: 48-50]
} 
Podkreślanie mocy illokucyjnej wypowiedzi, wzmocnienie argumentacji, przekonywanie, perswadowanie, podkreślanie szczerości lub stanowczości wypowiadanych sądów, to tylko niektóre z nich.

\section{Metaforyka prawdy}

Profesor Jadwiga Puzynina analizując zebrane hipotezy etymologiczne różnych nazw prawdy zauważa,, że mogą one sugerować związki leksemu prawda z tym, co jawne, oczywiste. Po drugie może zachodzić związek z tym, co jasne (co jest widoczne, co jest światłem dla człowieka). Kolejny - z tym, co mocne, dające oparcie, wiarygodne. Następne związki to: z tym, co wybrane jako przekonanie (prawda rozumiana jako wybrany przez człowieka sąd o rzeczywistości), z tym, co proste i prowadzące naprzód, takie, jakie powinno byće ${ }^{2}$. Obok tych związków dostrzec można prawdziwe/ukryte przestanie, czy glębszy/ ukryty sens. Związki prawdy z tym, co jawne, oczywiste, jasne, wiarygodne, proste wybrzmiewają przez „powiedzmy otwarcie”, „powiedzmy sobie szczerze”, „miedzy Bogiem a prawdą”, „między nami mówiąc”. Szczególnym przypadkiem jest „prawdziwe oblicze/życie (kogoś)", gdyż mamy tu do czynienia dopiero z odkrywaniem prawdy, prawdy skrywanej, ukrytej, głębokiej.

Ludzie prawdę uświadamiają sobie, szukają jej. Prawda bywa niełatwa, niejasna, zagmatwana, poplątana. Prawdy się dochodzi, ujawnia się ją. Prawda czasem jest gorzka, przykra, smutna. Bolesną prawdę się wygarnia. Od prawdy można się odwracać, można się z nią mijać a nawet się jej bać. Można wybrać drogę prawdy, kroczyć nią, dać jej świadectwo. Na podstawie tych utrwalonych w języku ogólnym metaforyki prawdy, J. Puzynina wyciąga wnioski, że „jest to metaforyka przestrzenno-kierunkowo-ruchowa (głęboka prawda, dochodzić (do) prawdy, drogi prawdy), metaforyka światła (blask, słońce, promień, światło prawdy), smaku (gorzka prawda). Prawda jest często personifikowana lub przynajmniej animizowana (naga prawda, prawdy martwe i żywe, mijać się z prawda, zabić prawdę, wskrzesić ją, zwycięstwo prawdy, prawda wyzwala), w inny sposób konkretyzowana (ukrywać i odkrywać prawde, szukać jej, wygarniać ją, prawda w oczy kole; porównanie: prawda jak oliwa; źdźbło, ziarnko, ziarno prawdy)" ${ }^{21}$.

Relatywizm językowy uważa, iż język wypływa na sposób myślenia posługujących się nim ludzi. Niewątpliwie mowa odbija ludzkie myślenie. Skoro słownictwo danego języka wyraża preferencje użytkowników dla tego, co uważają oni za ważne, nie można nie zauważyć, że w przypadku wyrażenia tak naprawde mamy do czynienia ze zjawiskiem dualizmu prawdy. Poruszamy się w dwóch rzeczywistościach: udawanej i skrywanej, gdzie prawda raz będzie pozorna a drugi rzeczywista. Człowiek poznaje przeróżne gry językowe, reguły użycia języka, sposoby reagowania na słowa, odkrywa, kiedy jaka gra bardziej się opłaca. W języku jak w zwierciadle odbija się obraz pragnień, obaw oraz myśli społeczeństwa. Użycie wyrażenie tak naprawdę $\mathrm{w}$ pewnych sytuacjach komunikacyjnych przyjmuje postać strategii konspiracyjnej, gdyż tak naprawdę znaczy tyle co, „, przymrużeniem oka”, „nieoficjalnie”, „między nami”. Jednakże ludzie zagubieni w pozorach rzeczywistości, poszukują prawdy i domagają się jej „nie na żarty, ale tak naprawdę". 
Nie można pominąć problemu wieloaspektowości zjawiska prawdy. To nurtujące i głęboke zagadnienie, dotyka wiedzy z zakresu psychologii osobowości, socjologii, filozofii, etyki i językoznawstwa. Obrazy rzeczywistości, sposób widzenia, czy oceniania drugiego człowieka, siebie samego mają swoje odbicie w języku, i to język dostarcza bogactwa przykładów $\mathrm{z}$ zakresu wieloaspektowości prawdy. Przykłady? - tak niewinne z pozoru zwroty jak: „pokazał prawdziwą twarz”, „odsłonił swoje prawdziwe oblicze”, czy „odkrył swoją naturę”. Przez nie przebija przekonanie o istnieniu dwóch przynajmniej płaszczyzn, na jakich człowiek, do którego te słowa się odnoszą, funkcjonuje. Jedna twarz to ta widziana przez ludzi codziennie, druga to ta skrywana i niezwykle rzadka do zauważenia. Co ciekawe, to właśnie ta twarz uchodzi za tą prawdziwą. Twarz codzienna ujmowana jest w kategoriach maski, jaką się nakłada podczas gry w teatrze, którym jest życie, bądź podczas funkcji, ról społecznych pełnionych każdego dnia w społeczeństwie. Ta twarz nie jest uważana za prawdziwie szczerą i autentyczną. Prawdziwe oblicze jest skrywane.

Takie założenie o istnieniu w człowieku jego twarzy codziennej - maski i twarzy ukrytej - prawdziwej, nie pozostaje bez echa dla problemu tożsamości danej osoby. Niewątpliwie jedna, jak i druga twarz muszą stanowić integralny składnik tożsamości danej osoby. Ciekawą kwestią pozostaje rozstrzygnięcie, czy zwroty te padają w kontekście zetknięcia się z „obliczem” różnym od tego przyjętego, założonego, z jakim zawsze się stykamy w przypadku danej osoby, czy też zwroty te padają w sytuacji rozpoznania nowej cechy osobowości, poznania nowej wady/zalety u osoby dobrze znanej? Czy nie niepokoi w tej sytuacji rozwarstwienie człowieka na tego prawdziwego i tego udawanego oraz postrzeganie codziennego wymiaru jego egzystencji z perspektywy gry aktora w teatrze życia? Lęk budzi deprecjacja oblicza 'bycia na co dzień' oraz przeświadczenie o rozpoznaniu i uznania za kłamcę.

Za prawdziwością, pewnością kryje się wiara w to, że istnieje jakaś możliwość prawdy absolutnej, wystarczy żebyśmy byli ze sobą szczerzy i nie byli w teatrze, a wtedy prawdą byśmy ze sobą rozmawiali. To przekonanie oczywiście zakłada, że istnieje wiara i możliwość realizacji arystotelesowskiego widzenia prawdy. A może kryje się za tym ludzka potrzeba odniesienia do bytów w całości, układów, które nadają metafizyczny sens naszemu byciu? Niewykluczone, że to wyraz tęsknoty za światem prostym i szczerym.

\section{Zakończenie}

Faktem jest, że wyrażenie tak naprawdę jest silnie naaksjologizowane i niejednokrotnie kojarzone z tym, co jest dobre, słuszne, właściwe. Prawdą jest, że sposób odbierania przez ludzi otaczającej ich rzeczywistości, znajduje odzwierciedlenie $\mathrm{w}$ języku. Zawarte $\mathrm{w}$ wypowiedziach tak naprawdę często pełni rolę wzmacniacza prezentowanego stanowiska, wykorzystuje się je do narzucania oponentowi swoich racji, używa się go przy przekonywaniu oraz dla podkreślenia własnych emocji. Tak naprawdę zdaje się być uwikłane w sferę ludzkich uczuć, przekonań, wyborów, intuicji a nawet wiary i dlatego nie dziwi, że uzasadnienia dla prawdy, dla tego, co naprawdę obarczone są naturą uczuciową lub też racjonalną. Poruszają się w sferze empirycznej, metafizycznej, nie brak odniesień do tego, co naturalne, transcendentalne... Profesor Leszek Kołakowski w treści książki Jeśli 
Boga nie ma, nie zgadza się $\mathrm{z}$ tezą, jakoby język świecki był „autentyczny, obiektywny, opisowy, wolny od przyjętych z góry założeń i zdolny do przekazywania prawdy” ${ }_{22}$. Zauważa, że „świecka mowa roi się od słów naładowanych wartościowaniem lub odnoszących się do niesprowadzalnych faktów, w szczególności do naszych stanów wewnętrznych” ${ }^{23}$.

Tęsknota $\mathrm{i}$ wiara $\mathrm{w}$ prawdziwość, pewność czy oczywistość to nie tylko pożądane przez ludzi stany, ale to zarazem wskazówki pozwalające określić, do jakiego świata aspirujemy. Nie powinno to dziwić, skoro fundamentem funkcjonowania społeczeństwa jest zaufanie społeczne. Zakładany arystotelesowski obraz świata, przebijający przez wypowiedzi zawierające wyrażenie przysłówkowe tak naprawdę, jest sygnałem dla interlokutorów, że poruszają się w tym samym świecie - ładu i harmonii, że mogą sobie wzajemnie zaufać, a to pozwala na wytworzenie specyficznej atmosfery porozumienia. 
Bożena Niećko-Bukowska: Funkcjonowanie pojęcia prawdy na przykładzie potocznego użycia „tak naprawdę"

\section{Bibliografia}

Ajdukiewicz, K., 1983: Zagadnienia i kierunki filozofii, Warszawa.

Kołakowski, L., 1988: Jeśli Boga nie ma., Wydawnictwo Znak.

Grabias, S., 2003: Język w zachowaniach społecznych, Lublin, Wydaw. Uniwersytetu Marii Curie-Skłodowskiej.

Reale, G., 1994: Historia filozofii starożytnej, T. I, Lublin.

Legowicz, J., 1986: Historia filozofii starożytnej Grecji i Rzymu, Warszawa.

Platon, 2002: Gorgiasz, Wydawnictwo Antyk, Kęty.

Wittgenstein, L., 2000: Dociekania filozoficzne, Wydawnictwo Naukowe PWN.

Chapman, S., 2000: Philosophy for Linguists. An introduction, London and New York: Routledge.

Wołos, M., 2002: Koncepcja gry językowej Wittgensteina w świetle badań współczesnego językoznawstwa, Kraków: Universitas.

Janikowska, E., Wróbelek Maciuś w Afryce i inne bajki, Wydawnictwo PRINTEX.

Mała encyklopedia logiki, 1970: Wrocław - Warszawa - Kraków.

James, W., 1957: Pragmatyzm. Warszawa, Książka i Wiedza.

Puzynina, J., 1997: Słowo - wartość - kultura, Lublin, Towarzysto Naukowe KUL.

Puzynina, J., 1992: Język wartości, Warszawa, Wydawnictwo Naukowe PWN. 